Bartın Üniversitesi

Eğitim Fakültesi Dergisi

Cilt 6, Sayı 3, s. 902-914, Ekim 2017

BARTIN - TÜRKIYE

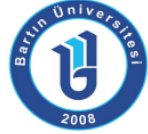

ISSN: 1308-7177
Bartin University

Journal of Faculty of Education

Volume 6, Issue 3, p. 902-914, October 2017

BARTIN - TURKEY

Doi: 10.14686/buefad.312405

\title{
Illkokul Müdürlerinin Etkili Liderlik Davranışları ile Okul Etkililiği Arasındaki iliş̧ki
}

\author{
Yusuf CERIT, Prof. Dr., Abant İzzet Baysal Üniversitesi Eğitim Fakültesi, cerit_y@ibu.edu.tr \\ ORCID: http://orcid.org/0000-0002-4961-8667 \\ Bilal YILDIRIM, Yrd. Doç. Dr., İstanbul Sabahattin Zaim Üniversitesi Eğitim Fakültesi, bilal.yildirim@izu.edu.tr \\ ORCID: http://orcid.org/0000-0001-6225-5859
}

Öz: Bu çalışmanın amacı ilkokul müdürlerinin etkili liderlik nitelikleri ile okul etkililiği arasındaki ilişkiyi incelemektir. Bu çalışmanın verileri 2016-2017 öğretim yılında Bolu il merkez ilçe sınırları içerisinde yer alan ilkokullarda görev yapan 257 sınıf öğretmeninden elde edilmiştir. Araştırmanın verileri Sharma (2010) tarafından geliştirilen ve Cerit, Kadıoğlu Ateş ve Kadıoğlu (baskıda) tarafından Türkçe'ye uyarlanan "Etkili Liderlik Nitelikleri Ölçeği” ile, Hoy (2014) tarafından geliştirilen ve Yıldırım (2015) tarafından Türkçe'ye uyarlanan "Algılanan Okul Etkililiği Ölçeği” kullanılarak elde edilmiştir. Verilerin analizinde aritmetik ortalama ve standart sapma, korelasyon ve regresyon analizi kullanılmıştır. Araştırmada etkili liderlik nitelikleri ile okul etkililiği arasında olumlu ve anlamlı ilişki olduğu ve etkili liderlik niteliklerinin okul etkililiğinin anlamlı bir yordayıcı olduğu bulunmuştur.

Anahtar Kelimeler: liderlik, etkili liderlik nitelikleri, okul etkililiği

\section{The Relationship Between Primary School Principals' Effective Leadership Behaviours and School Effectiveness}

\begin{abstract}
The purpose of the this study was to explore the relationship between primary principals' effective leadership qualities and school effectiveness. Data in this study were collected from a total number of 257 classroom teachers. Classroom teachers' perceptions of school effectiveness was measured using perceived school effectiveness scale developed by Hoy (2014) and was adapted by Yıldırım (2015), and effective leadership qualities was measured using effective leadership qualities developed by Sharma (2010) and was adapted by Cerit, Kadıoğlu Ateş ve Kadıoğlu (in review). Mean, standard deviation, correlation and regression test used in analysis of the data. Data analysis indicated that there was a significant positively correlation between effective leadership qualities and perceived school effectiveness, and effective leadership qualities was significantly predictor of perceived school effectiveness.
\end{abstract}

Key Words: leadership, effective leadership qualities, school effectiveness 


\section{GiRiş}

Eğitimsel gelişme ve değişmenin, sıklıkla okul yönetiminin niteliğine bağlı olduğuna inanılır. Okul profesyonellerinin görevleri ve sorumlulukları, yaşam niteliğini artırma ve kendi farkındalıklarını gösterme, kendi kendilerini geliştirme ile toplumlar ve kültürle ilgili sorunları anlamak için öğrencilere yardım etmeyi içerir. Eğitim, gelecek nesillerin düşüncelerini besleme ve geliştirmeye katkı yaptığından toplumların geleceği için yatırım aracı olarak düşünülür. Bu yüzden eğitimi ve eğitim sistemini iyileştirmek için eğitim üzerinde etkiye sahip olan faktörleri araştırmak önemlidir (Laila, 2015). Bu nedenle eğitim hizmetinin verildiği kurumlar olan okulların etkili şekilde faaliyet göstermelerine odaklanılmış ve okulların etkililiğinin sağlanabilmesi için neler yapılması gerektiği araştırmalara konu olmuştur.

Alan yazında okul etkililiği kavramının tanımında bir uzlaşma sağlanamamasına rağmen birçok tanımı yapılmıştır. Bu tanımlardan bazıları şu şekildedir; Klopf, Schelden ve Brennan (1982) okul etkililiğini öğrencilerin bilişsel, duyuşsal, psikomotor, sosyal ve estetik gelişimlerinin en uygun biçimde desteklendiği optimum bir öğrenme çevresinin yaratılması şeklinde tanımlamıştır (Akt. Balcı, 2001). Tatlah ve Igbal (2012) tarafından okul etkililiği, çocukların başarısı olarak tanımlanmıştır. Okul etkililiği, öğrencilerle ilgili bireysel verilere dayalı olarak belirlenen okul puanıdır (Balcı, 2001). Creemers ve Reezigt (1997) okul etkililiğini, eğitimsel süreçler ve sonuçlar arasındaki amaç-araç ilişkileriyle, özelliklede okullar ve sınıflar arasındaki öğrenci başarısındaki farklııkları açıklamayı amaçlayan öğrenci bilgi ve becerileriyle ilgili bütün teori ve araştırmaların sonucu olarak tanımlamıştır. Reezigt ve Creemers (2005)'e göre okul etkililiği güçlü bir şekilde öğrenci sonuçlarına ve bu sonuçlarla ilişkili okul ve sınıf özelliklerine odaklanır. Bu yüzden okul etkililiği, okulların sahip oldukları materyalleri, donanımı ve fiziksel çevresini kullanarak öğretmenlerin öğrencileri için oluşturdukları hedeflere ulaşma düzeyleri olarak tanımlanabilir (Laila, 2015). Bu tanımlamalardan anlaşılabileceği gibi okul etkililiği genel olarak öğrencilerin gelişimi ve başarılarına dayalı olarak açıklanmıştır.

Alan yazında etkili okulların farklı araştırmacılar tarafından özellikleri tanımlanmıştır. Örneğin, Edmund (1979) etkili okulun özelliklerini güvenli ve düzenli bir çevre, öğrencilerden yüksek beklentiler, görevleriyle ilgili öğrenme fırsatı, güçlü öğretimsel liderlik, öğrencilerin ilerlemesinin sıklıkla izlenmesi, olumlu okul-aile ilişkisi ve açık bir okul misyonu şeklinde ifade etmişlerdir (Akt. Trujillo, 2013). Okul etkililiği üzerine yapılan birçok çalışmada etkili okulun; 1) güçlü öğrenme çevresi, 2) güçlü öğretimsel liderlik, 3) yüksek personel morali, 4) delile dayalı karar verme, 5) yüksek öğretmen yeterliği şeklinde beş özelliğinin olduğu ortaya çıkmıştır (Hofman ve Hofman, 2011; Sammons, Gu, Day ve Ko, 2011; Wang, Walters ve Thum, 2013). Bununla birlikte etkili bir okul, öğretmenleri çalışmaya teşvik edici bir vizyona, açık ortak amaç ve hedeflere, etkili bir iletişime, çocukların görüşlerini ifade edebilme ve öğretmenlerle etkileşimi kurabilmeyi destekleyen, çocukların kişisel ve sosyal gelişimini besleyen, nitelikli personel ve iyi uzmanlara sahip olan iyi bir çevredir (Purkey ve Smith, 1993).

Birçok ülkede (ABD, İsviçre, Hollanda, İngiltere, Finlandiya, İtalya v.b.) eğitim araştırmacıları ve politikacılarının öğrencilerin iyi şekilde yetiştirilebilmeleri ile ilgilenmeleri, okulların etkililiği üzerinde yoğun şekilde çalışmaların yapılmasına neden olmuştur (Day, Gu ve Sammons, 2016). Okul etkililiği ile ilgili çalışmaların bazıları okulların etkililik düzeylerine veya etkili okulların özelliklerinin belirlenmesine odaklanırken (Hofman ve Hofman, 2011; Wang v.d., 2013), bazı çalışmalarda okul etkililiğini etkileyen faktörlere odaklanılmıştır (Bolanle, 2013; Tatlah ve Iqbal, 2012). Konuyla ilgili çalışmalar okul müdürlerinin liderlik davranışlarının okul etkililiğini etkileyen önemli bir faktör olduğunu göstermiştir (Tatlah ve Iqbal, 2012). Okul liderliği, hedef oluşturma, paydaşların ihtiyaçlarına duyarlılık gösterme ve hedeflere ulaşmayı sağlama gibi birçok açıdan eğitim kurumlarının etkililiğinde vazgeçilmez bir rol oynamaktadır (Odhiambo ve Hii, 2012; Parylo ve Zepeda, 2014; Sharma, 2010). Okul yöneticileri, eğitimsel ve 
yönetimsel seçimlerini veya iyi politikaları uygulamaya dönüştürmedeki başarısızlığı okulların etkililiği açısından sorunlar oluşturabilecektir (Hofman ve Hofman, 2011).

Alan yazında okul etkililiği açısından müdürlerin liderlik niteliklerini belirlemeye yönelik çalışmalar yapılmıştır (Sammons v.d., 2011; Wallin, 2003). Bu çalışmalarda okul müdürlerinin liderlik nitelikleri şu şekilde belirlenmiştir: 1) Yönlendirme: Etkili okullarda müdürler aile, öğrenci ve öğretmenlerle işbirliği içerisinde misyon, hedef ve amaçlar oluştururlar. 2) Öğrencilerin öğrenmelerini sağlama: Etkili okullarda müdürler öğrencilerin başarısını artırabilmek için koordine edilmiş bir okul planı geliştirir ve yerleştirirler. 3) Okul iklimi: Etkili okullarda müdürler, öğretmenlerin seçimi ve atanması ile performanslarının değerlendirilmesi için bir yöntem geliştirirler ve öğretmenlere ilgi gösterme eğilimindedirler. 4) Mesleki gelişme: Etkili okullarda müdürler öğretmenlerin ve kendilerinin mesleki gelişimleri için bir program oluştururlar (Wallin, 2003). Sammons v.d. (2011) okul liderliğinin öğrenciler ve öğretmenlerin çalışmalarında yüksek beklentiler oluşturmayı ve işbirlikçi çalışmayı içeren yönlendirme; öğretim etkinliklerini geliştirmek için yeni fikirler üretmeye öğretmenleri teşvik etmeyi kapsayan insanları geliştirme; öğretmenler arasında işbirliği içerisinde çalışmayı teşvik etme, işleyiş sürecini iyileştirme ve kaynakların dağıtımında çocukların ihtiyaçlarını dikkate almayı içeren örgütü yeniden dizayn etme; çalışmalarında verileri kullanmayı teşvik etmeyi kapsayan veri kullanma; sınıf etkinliklerini düzenli olarak gözleme ve öğretimi iyileştirmek için öğretmenlerle çalışmayı kapsayan gözlemi kullanabilme becerilerine sahip olmaları gerektiğini ileri sürmüşlerdir. Okul liderleri, vizyon oluşturma, etkileme, öğretmenlerin entelektüel uyarımına saygı duyarak çalışma istekliliklerini artırma, ödüllendirme ve akademik liderlik yoluyla okul etkililiğine katkı sağlayabileceklerdir (Boonla ve Treputtharat, 2014). Bolanle (2013) tarafından yapılan çalışmada okulun etkililiğini sağlayabilmek için okul müdürlerinin teknik, insan ilişkileri, dönüşümsel ve ortamsal liderlik becerilerine sahip olmalarının kritik olduğu ortaya çıkmıştır. Laila (2015) tarafından yapılan çalışmada öğretmenler, okulun etkililiğini sağlayabilmek için okul liderlerinin sahip olması gereken rolleri; okul için açık vizyon oluşturma, bir öğrenme toplumu oluşturma, öğrencilerin ilerlemelerini izleme, hem personel hem de öğrenciler için yüksek düzeyde ulaşılabilir olma, okulun sürekli gelişiminde başarıya ulaşma, öğretmenlerin karar verme sürecine katıımını sağlama ve öz saygılarını artırma olarak sıralamıştır.

Okul etkililiği ile okul müdürlerinin liderlik nitelikleri arasındaki ilişkinin varlı̆̆ı yapılan birçok çalışmada ortaya çıkmıştır (Bolanle, 2013; Boonla ve Treputthrat, 2014; Hallinger ve Heck, 2010; Hofman ve Hofman, 2011; Kazancıoğlu, 2008; Yılmaz, 2010). Okul liderliği ile okul etkililiği arasında ilişkiyi inceleyen çalışmalarda, okul liderliğinin okulun etkililiği üzerinde doğrudan ve dolaylı olarak etkisinin olduğu ortaya çıkmıştır (Bolanle, 2013; Boonla ve Treputthrat, 2014; Hallinger ve Heck, 2010; Hofman ve Hofman, 2011; Kazancıoğlu, 2008; Sammons v.d., 2011; Tatlah ve Iqbal, 2012; Yılmaz, 2010). Yılmaz (2010) tarafından yapılan çalışmada okul müdürlerinin öğretimsel liderlik davranışlarını yerine getirme düzeylerinin öğretmenlerin okullarının etkili olduğunu düşünmelerini olumlu şekilde etkilediği ortaya çıkmıştır. Müdürler öğretime odaklanma, öğretim ve öğretmenler için kaynakların temini ve erişebilirliğini sağlama, olumlu okul ve öğrenme iklimini oluşturma yoluyla öğrencilerin öğrenmelerini sağlayarak okulun etkililiği üzerinde etkili olmaktadır (Hallinger, Bickman ve Davis, 1996). Ayrıca okul liderlerinin öğretmenlerin motivasyonunu artırma ve öğretim etkinliklerini nitelikli şekilde gerçekleştirebilmelerinde destek sağlamaları öğrenci performanslarına olumlu şekilde yansımaktadır (Fullan, 2001). Bununla birlikte okul kültürünü şekillendirme yoluyla da okul liderleri okul etkililiği üzerinde etkili olmaktadır (Witziers, Bosker ve Kruger, 2003). Hallinger (2010) çalışmasında müdürlerin liderliklerinin işbirlikçi öğrenme kültürü oluşturma, öğretmen gelişimini sağlayan bir yapı ve kültür, öğrencilerin motivasyonu, katılımı ve başarısını artıran bir okul iklimi geliştirme yoluyla okul etkililiği üzerinde etkiye sahip 
olduğunu vurgulamıştır. Day v.d. (2016) çalışmalarında okul liderlerinin, okulun ihtiyaçlarını belirleme ve anlama, öğretimsel uygulamaları açık şekilde ifade etme ve ortak örgütsel değerler geliştirme yoluyla okul etkililiğini etkilediği ortaya çıkmıştır. Okul liderleri güvenli ve düzenli öğrenme çevreleri oluşturabilmek için yoğun şekilde çalışma, açık öğretimsel hedefler oluşturma, öğrenci ve öğretmenlerden yüksek performans beklentilerine sahip olma ve olumlu aile-okul işbirliğini geliştirme yoluyla okulun etkililiğine katkı yaparlar (Jacobson, 2011).

Leithwood, Anderson, Mascall ve Straus (2010) okul liderlerinin öğrencilerin öğrenme ve okul sonuçlarını etkilemesinin dört yolla gerçekleştiğini belirtmiştir: okul müdürlerinin problem çözme kapasiteleri ile liderlik ve pedagojik bilgilerini kullanarak öğretmenlerin pedagojik davranışı ve yeterliliklerini etkileyebilme niteliğini içeren rasyonel yol; müdürlerin esinlendirme ve destekleme yoluyla öğretmenlerin duygusal durumlarını etkilemelerini ifade eden duygusal yön; müdürlerin profesyonel veya bürokratik eğilimlerini gösteren iş süreç ve prosedürlerinin organizasyonu ve okulun formal yapısına vurgu yapan örgütsel yön; ve okul müdürlerinin etkilerine daha az bağlı olan öğrencilerin kişisel özelliklerini ifade eden aile yönüdür. Babaoğlan, Nalbanti ve Çelik (2017) tarafından yapılan çalışmada da okul müdürlerinin öğretmenleri ve öğrencileri güdüleme ve olumlu ilişkiler kurarak okulların işleyişi ve başarısını etkileyebildikleri ortaya çıkmıştır. Kazancıoğlu (2008) ise demokratik liderliği benimseyen müdürlerin okulu gelişmesine ve ilerlemesine yönelik yenilik arayışları ve olumlu ilişkiler yoluyla okul etkililiğini sağlayabileceklerini ileri sürmüştür.

Yukarıda açıklamalar ve araştırma sonuçları okul müdürlerinin liderlik davranışlarının okulun etkililiği üzerinde etkili olduğunu göstermektedir. Alan yazında çoğunlukla okulun etkililiği öğrencilerin başarı düzeyleri üzerinden değerlendirilmiştir. Öğrencilerin öğrenme süreçlerinin çoğunlukla öğretmenler tarafından yönetildiği dikkate alındığında, okul liderlerinin öğretmenlerin iş doyumu, motivasyonu, bağlılığı ve mesleki gelişimleri gibi değişkenleri etkileyerek dolaylı olarak öğrencilerin başarılarına katkı yaptığı ifade edilebilir. Öğretmenlerin görüşlerine dayalı olarak okul müdürlerinin liderlik nitelikleri ile okul etkililiği arasındaki ilişkin incelenmesinin, okul etkililiğini etkileyebilecek liderlik niteliklerinin neler olduğunun ve bu liderlik niteliklerinin hangi oranda okul etkililiği ile ilişkili olduğunun belirlenmesine katkı sağlayabileceği düşünülmektedir. Ayrıca yurtdışı alan yazında okul müdürlerinin liderlik davranışlarının okul etkililiği üzerinde etkisi araştırılmasına rağmen Türkiye'de etkili liderlik nitelikleri ile okul etkililiği arasındaki ilişkiyi inceleyen çalışmalara ulaşılabildiği kadarıyla rastlanmamıştır. Bu nedenle bu çalışmada öğretmenlerin görüşlerine dayalı olarak okul etkililiği ile okul müdürlerinin etkili liderlik nitelikleri arasındaki olası ilişkiler ortaya çıkarılmaya çalışılımıştır.

\subsection{Araştırmanın Amacı}

Bu çalışmada sınıf öğretmenlerinin algılarına dayalı olarak okul müdürlerinin etkili liderlik niteliklerine sahip olma düzeyleri ile okul etkililiği arasındaki ilişkinin belirlemesi amaçlanmıştır. Bu amaç doğrultusunda aşağıdaki sorulara yanıt aranmıştır;

1. Sınıf öğretmenlerinin okullarının etkililik düzeyine ilişkin algıları nelerdir?

2. Sınıf öğretmenlerinin okul müdürlerinin etkili liderlik niteliklerine sahip olma düzeyine ilişkin algıları nelerdir?

3. Sınıf öğretmenlerinin algılarına göre okul müdürlerinin etkili liderlik niteliklerine sahip olma düzeyleri ile okul etkililiği arasında istatistiksel olarak anlamlı bir ilişki var mıdır?

4. Sınıf öğretmenlerinin algılarına göre okul müdürlerinin etkili liderlik niteliklerine sahip olma düzeyleri okul etkililiğinin istatistiksel olarak anlamlı bir yordayıcısı mıdır?

\section{YÖNTEM}




\subsection{Araştırmanın Modeli}

Ilkokul müdürlerinin etkili liderlik niteliklerine sahip olma düzeyleri ile okul etkililiği arasındaki ilişkinin incelendiği bu çalışmada ilişkisel tarama modeli kullanılmıştır.

\subsection{Katılımcilar}

Bu çalışmanın evrenini Bolu ili merkez ilçe sınırları içerisinde yer alan 22 ilkokulda görev yapan 351 sınıf öğretmeni oluşturmuştur. Araştırmada evrene ulaşma olasılığı bulunduğu için örneklem seçilmemiş evrenin bütününden konu ile ilgili bilgiler elde edilmiştir. Ancak evrende yer alan 19 öğretmene ulaşılamadığı ve 75 öğretmen ise araştırmaya katılmak istemedikleri için bu çalışmanın katılımcılarını 257 sınıf öğretmeni oluşturmuştur. Sınıf öğretmenlerinin \% 56.4'ü kadın (n:145), \% 43.5'i (n:112) ise erkektir. Öğretmenlerin \% 8,5'i (n:22) yüksekokul, \% 79.3'ü (n: 204) fakülte ve \% 12'si (n:31) ise yüksek lisans eğitimi almıştır. Öğretmenlerin \% 6.2'si (n:16)1-5 yıl, \% 10.11'i (n:26) 6-10 yıl, \% 26.4'ü (n:68) 11-15 yıl, \% $30.3^{\prime} \ddot{u}$ (n: 78)16-20 yıl ve \% 26.8'i (n:69) ise 21 yıl ve üzerinde mesleki kıdeme sahiptirler.

\subsection{Verilerin Toplanması}

Araştırmada okul müdürlerinin etkili liderlik niteliklerine sahip olma düzeylerini belirlemek için Sharma (2010) tarafından geliştirilen ve Cerit, Kadıoğlu Ateş ve Kadıoğlu (basım aşamasında) tarafından Türkçe'ye uyarlanan Etkili Liderlik Nitelikleri Ölçeği, sınıf öğretmenlerinin okulun etkililiğine ilişkin görüşlerini belirlemek için ise Hoy (2014) tarafından geliştirilen ve Yıldırım (2015) tarafından Türkçe’ye uyarlanan Algılanan Okul Etkililiği Ölçeği kullanılmıştır.

Algılanan Okul Etkililiği Ölçeği: Sınıf öğretmenlerinin okul etkililiğine ilişkin görüşlerini belirlemek için kullanılan Algılanan Okul Etkililiği Ölçeği 8 maddeden oluşmaktadır. Ölçek ile ilgili örnek maddeler: "Bu okuldaki öğretmenler mevcut kaynakları etkili bir şekilde kullanırlar.", "Bu okulda sunulan ürün ve hizmetlerin kalitesi yüksektir." Ölçeğin puanlamasında 1 (Kesinlikle Katılmıyorum) ile 6 (Tamamen Katılıyorum) arasında dereceleme kullanılmıştır.

Algılanan okul etkililiği ölçeğinin 8 maddelik yapısının bu çalışmanın verileriyle uyum gösterip göstermediğini belirlemek amacıyla doğrulayıcı faktör analizi (DFA) yapılmıştır. Modelin uyum iyiliği düzeyini belirlemek için $\mathrm{X}^{2} / \mathrm{df}$, RMSEA (Yaklaşık Hataların Ortalama Karekökü), GFI (Uyum İyiliği İndeksi), ve CFI (Karşılaştırmalı Uyum İndeksi) istatistikleri kullanılmıştır. DFA sonuçları $\left(X^{2}=194.421, \mathrm{df}=58, \mathrm{X}^{2} / \mathrm{df}=3.35, \mathrm{RMSEA}=.05, \mathrm{CFI}=.94, \mathrm{GFI}=.90\right)$ algılanan okul etkililiği ölçeğinin 8 maddelik yapısının uyum indeksinin iyi olduğunu göstermiş̧ir. Buna ilaveten ölçeği oluşturan maddelerin parametre değerleri .73 ile .91 arasında değişmiştir. Sonuç olarak ölçeğin 8 maddelik yapısı bu çalışma verileri ile yapılan analizlerde de doğrulanmıştır. Bu çalışmada ölçeğin açıkladığı varyansın $\% 75.30$ olduğu belirlenmiştir.

Ölçeğin güvenirlik çalışması için Cronbach alfa katsayısı tespit edilmiştir. Ölçeğin alfa değeri .89, madde toplam korelasyonu .56 ile .76 arasında değiştiği bulunmuştur. Buna göre, ölçeğin iç tutarlılığının bulunduğu söylenebilir.

Etkili Liderlik Nitelikleri Ölçeği: Araştırmada okul müdürlerinin etkili liderlik niteliklerine sahip olma düzeylerini belirlemek amacıyla Sharma (2010) tarafından geliştirilen 40 maddelik ölçeğin Sun, Wang ve Sharma (2014) tarafından kısaltılmış formu olan ve Cerit, Kadıoğlu Ateş ve Kadıoğlu (basım aşamasında) tarafından Türkçe'ye uyarlanan ve 16 maddeden oluşan Etkili Liderlik Nitelikleri Ölçeği kullanılmıştır. Ölçek ile ilgili örnek maddeler: "Okul müdürüm öğretmelerin yaşamlarının her yönüyle ilgilenirler.", "Okul müdürüm okulda bir aile atmosferi yaratır." Ölçeğin puanlamasında 1 (Hiç Katılmıyorum) ile 5 (Tamamen Katılıyorum) arasında dereceleme kullanıımıştır. 
Etkili Liderlik Nitelikleri Ölçeği'nin 16 maddelik yapısının bu çalışmanın verileriyle uyum gösterip göstermediğini belirlemek amacıyla doğrulayıcı faktör analizi (DFA) yapılmıştır. Modelin uyum iyiliği düzeyini belirlemek için $\mathrm{X}^{2} / \mathrm{df}$, RMSEA (Yaklaşık Hataların Ortalama Karekökü), GFI (Uyum İyiliği İndeksi), ve CFI (Karşılaştırmalı Uyum Indeksi) istatistikleri kullanılmıştır. DFA sonuçları $\left(X^{2}=201.425, \mathrm{df}=54, \mathrm{X}^{2} / \mathrm{df}=3.73\right.$, RMSEA=.06, $\left.\mathrm{CFI}=.92, \mathrm{GFI}=.90\right)$ algılanan okul etkililiği ölçeğinin 16 maddelik yapısının uyum indeksinin iyi olduğunu göstermiştir. Buna ilaveten ölçeği oluşturan maddelerin parametre değerleri .69 ile .94 arasında değişmiştir. Sonuç olarak ölçeğin 16 madde ve 8 faktörlü yapısının bu çalışmada geçerli bir yapı olduğu ortaya çıkmıştır.

\section{Tablo 1}

Etkili Liderlik Nitelikleri Ölçeği Boyutları ve Cronbach Alfa Değerleri

\begin{tabular}{llcc}
\hline Boyut No & Boyut Adı & Madde Sayısı & Cronbach Alfa \\
\hline 1 & Öz Yönetim & 2 & .66 \\
2 & Zaman Yönetimi & 2 & .92 \\
3 & Etki & 2 & .82 \\
4 & Rahat Ettirme & 2 & .84 \\
5 & Karar Verme & 2 & .83 \\
6 & Bağılık & 2 & .86 \\
7 & Iletişim & 2 & .86 \\
8 & Empati & 2 & .86 \\
\hline
\end{tabular}

Ölçeğin güvenirlik çalışması için Cronbach alfa katsayısı tespit edilmiştir. Analiz sonucunda öz yönetim faktörünün Cronbach alfa değeri . 66, zaman yönetimi faktörünün alfa değeri .92, etki faktörünün alfa değeri .82 , rahat ettirme faktörünün alfa değeri .84 , karar verme faktörünün alfa değeri .83 , bağlılık faktörünün alfa değeri .86 , iletişim faktörünün alfa değeri .86 ve empati faktörünün alfa değeri .81 bulunurken toplam ölçeğin alfa değeri ise .94 bulunmuştur. Ölçeğin madde-toplam korelasyonun .74 ile .86 arasında değiştiği bulunmuştur. Buna göre, ölçekteki maddelerin Etkili Liderlik Niteliklerini ölçmeye yönelik olduğu yani iç tutarlıı̆ıııı bulunduğu ifade edilebilir.

\subsection{Verilerin Analizi}

Sınıf öğretmenlerinin okulun etkililiğine ilişkin algıları ile okul müdürlerinin etkili liderlik niteliklerine sahip olma düzeylerini belirlemek için aritmetik ortalama ve standart sapma değerleri kullanılmıştır.

Öğretmenlerin okul etkililiğine ilişkin algıları ile müdürlerin etkili liderlik niteliklerine sahip olma düzeyleri arasındaki ilişkiyi belirlemek için Pearson Momentler Çarpımı Korelasyon Analizi kullanılmıştır. Okul müdürlerinin etkili liderlik niteliklerine sahip olma düzeylerinin öğretmenlerin okul etkililiğine ilişkin algıları üzerinde ne düzeyde etkili olduğuna yönelik ise Çoklu Regresyon analizi yapılmıştır.

\section{BULGULAR}

Bu araştırmada sınıf öğretmenlerinin ilkokul müdürlerinin etkili liderlik niteliklerine sahip olma düzeylerine ilişkin görüşleri ile öğretmenlerin okul etkililiğine ilişkin algılarını belirlemek için hesaplanan aritmetik ortalama ve standart sapma değerleri Tablo 2'de verilmiştir. Aritmetik ortalama değerlerine göre, sınıf öğretmenlerinin okul müdürlerinin etkili liderlik niteliklerine orta düzeyde sahip olduklarını düşündükleri ifade edilebilir $(\bar{X}: 2.95$, ss: .60). Öğretmenlerin okul müdürlerinin en fazla zaman yönetimi ( $\overline{\mathrm{X}}: 3.06$, ss: .86$)$ ve öz yönetim niteliklerine ( $\bar{X}: 3.04$, ss: .82$)$, en az ise iletişim niteliğine ( $\bar{X}: 2.79$, ss: .63) sahip 
olduklarını düşündükleri ortaya çıkmıştır. Tablo 2'deki aritmetik ortalama değerlerine göre, sınıf öğretmenlerinin çalıştıkları okulların ortalamaya yakın bir düzeyde etkili olduğu düşüncesine sahip oldukları ifade edilebilir ( $\bar{X}: 2.90$, ss: .72).

Tablo 2

Sını Öğretmenlerinin Etkili Liderlik Nitelikleri ve Okul Etkililiğine Ilişskin Görüşleri

\begin{tabular}{lcc} 
Değişkenler & $\overline{\mathrm{X}}$ & ss \\
\hline Okul Etkililiği & 2.90 & .72 \\
Özyönetim & 3.04 & .82 \\
Zaman Yönetimi & 3.06 & .86 \\
Etki & 2.83 & .62 \\
Rahat Ettirme & 2.85 & .85 \\
Karar Verme & 2.95 & .82 \\
Bağılık & 3.09 & .87 \\
Illetişim & 2.79 & .63 \\
Empati & 2.87 & .64 \\
Toplam Liderlik Nitelikleri & 2.95 & .60 \\
\hline
\end{tabular}

Sınıf öğretmenlerinin okul etkililiğine ilişkin algıları ile müdürlerin etkili liderlik niteliklerine sahip olma düzeyleri arasındaki ilişkiyi belirlemek için yapılan korelasyon analizi sonuçları Tablo 3'de verilmiştir. Tablo 3'deki korelasyon değerlerine göre sınıf öğretmenlerinin okul etkililiğine ilişkin algıları ile karar verme ( $r: .530, p<.01)$, etki $(r: .488, p<.01)$, rahat ettirme ( $r: .472, p<.01)$, bağlılık ( $r: .453, p<.01)$ ve empati boyutları $(r: .415, p<.01)$ arasında anlamlı, olumlu ve orta düzeyde ilişki olduğu, öz yönetim ( $r$ : .392, $p<.01)$, zaman yönetimi ( $r$ : $.266, p<.01)$ ve iletişim boyutları $(r: .236, p<.01)$ arasında ise anlamlı olumlu ve düşük düzeyde ilişki olduğu ifade edilebilir. Korelasyon analizi sonuçları etkili liderlik niteliklerine sahip olma ile okul etkililiği ( $\mathrm{r}$ : .516, p: .000) arasında anlamlı ve olumlu bir ilişki olduğunu göstermiştir. Bu sonuçlara göre okul müdürlerinin etkili liderlik niteliklerine sahip olduğunu düşünen sınıf öğretmenlerinin okullarının daha etkili olduğunu düşündükleri ifade edilebilir.

Tablo 3

Etkili Liderlik Nitelikleri ile Okul Etkililiği Arasındaki Korelasyon Analizi Sonuçları

\begin{tabular}{lc}
\hline Değişkenler & Okul Etkililiği \\
\hline Özyönetim & $.392^{*}$ \\
Zaman Yönetimi & $.266^{*}$ \\
Etki & $.488^{*}$ \\
Rahat Ettirme & $.472^{*}$ \\
Karar Verme & $.530^{*}$ \\
Bağlılık & $.453^{*}$ \\
Illetişim & $.236^{*}$ \\
Empati & $.415^{*}$ \\
Toplam Liderlik Nitelikleri & $.516^{*}$ \\
\hline *P< 01 &
\end{tabular}

Etkili liderlik niteliklerinin sınıf öğretmenlerinin okul etkililiğine ilişkin algıları üzerinde etkiye sahip olup olmadığını belirlemek için yapılan çoklu regresyon analizi sonuçları Tablo 4'de verilmiştir. Regresyon analizi sonuçları empati, iletişim, etki, rahat ettirme, karar verme, 
bağlılık, öz yönetim ve zaman yönetimi boyutlarının birlikte öğretmenlerin okul etkililiği algılarının anlamlı bir yordayıcısı olduğunu göstermiştir $\left(R^{2}=.469, F_{(8,248)}=27.485, p=.000\right)$. Bu faktörler birlikte öğretmenlerin okul etkililiği algılarının \% 46.9'unu açıklamaktadır. Standardize edilmiş regresyon katsayılarına $(\beta)$ göre öğretmenlerin okul etkililiği algıları üzerinde en çok zaman yönetimi boyutunun, en az ise bağ ılık boyutunun etkide bulunduğu tespit edilmiştir. Regresyon analizinin anlamlılı̆ına ilişkin $t$ test sonuçları incelendiğinde ise, empati boyutunun $(\beta=.043 ; t=.408 ; p>.05)$ anlamlı bir etkisinin olmadı̆̆ı, özyönetim $(\beta=.224 ; t=3.146 ; p<.01)$, zaman yönetimi $(\beta=.385 ; t=4.226 ; p<.01)$, etki $(\beta=.247 ; t=.247 ; p<.01)$, rahat ettirme $(\beta=.271$; $t=3.689 ; p<.01)$, karar verme $(\beta=.354 ; t=4.046 ; p<.01)$, bağlılı $(\beta=.196 ; t=2.042 ; p<.05)$, ve iletişim ( $\beta=.243 ; t=2.592 ; \beta<.01)$ boyutlarının ise öğretmenlerin okul etkililiği algıları üzerinde anlamlı bir etkiye sahip olduğu görülmektedir. Bu sonuçlara göre etkili liderlik niteliklerinin öğretmenlerin okul etkililiği algılarının önemli bir yordayıcısı olduğu ifade edilebilir.

Tablo 4

Etkili liderlik nitelikleri ile okul etkililiğine ilișkin Regresyon Analizi Sonuçları

\begin{tabular}{lccccc}
\hline Değişkenler & $\mathrm{B}$ & $\begin{array}{c}\text { Standart } \\
\text { Hata }\end{array}$ & $\beta$ & $\mathrm{t}$ & $\mathrm{p}$ \\
\hline Özyönetim & .196 & .062 & .224 & 3.146 & $.002^{*}$ \\
Zaman Yönetimi & .320 & .076 & .385 & 4.226 & $.000^{*}$ \\
Etki & .287 & .099 & .247 & 2.898 & $.004^{*}$ \\
Rahat Ettirme & .230 & .062 & .271 & 3.689 & $.000^{*}$ \\
Karar Verme & .311 & .077 & .354 & 4.046 & $.000^{*}$ \\
Bağ|IIIk & .161 & .079 & .196 & 2.042 & $.043^{* *}$ \\
Iletişim & .278 & .107 & .243 & 2.592 & $.010^{* *}$ \\
Empati & .048 & .113 & .043 & .408 & .684 \\
\hline $\mathrm{R}=.685 ; \quad \mathrm{R}^{2}=.469$ & $\mathrm{~F}_{(8,248)}=27.485$ & $\mathrm{p}=.000$ \\
\hline \multicolumn{7}{c}{$\mathrm{P}<.01,{ }^{* *} \mathrm{P}<.05$} & \multicolumn{7}{c}{}
\end{tabular}

\section{TARTIŞMA}

Günümüzde toplumun en önemli yatırımının insanların eğitimi olduğu kabul edilmeye başlanmıştır (Mulford, 2003). Toplumlar, üyelerini ekonomik yaşamın gerektirdiği niteliklere sahip bireyler olarak yetiştirmenin yanında, onların bireysel ve sosyal açıdan gelişimlerine ve vatandaşlık bilincine sahip olmalarını sağlamaya çaba göstermektedirler. Bu da ülkelerin eğitime verdikleri önemin artmasına ve eğitim hizmeti veren kurumlar olarak okulların işleyiş şekline odaklanılmasına yol açmıştır. Bu çalışmada sınıf öğretmenlerinin, görev yaptıkları okulların orta düzeyde etkili olduğunu düşündükleri sonucuna ulaşılmıştır. Konuyla ilgili Türkiye'de yapılan çalışmaların bazılarında bu çalışmanın bulgusuyla paralel şekilde öğretmenlerin okullarının orta düzeyde etkili olduğunu düşündükleri bulunurken (Arslan, Satıcı ve Kuru, 2006; Şenel ve Buluç, 2016), bazı çalışmalarda ise öğretmenlerin okullarının ortalamanın üzerinde etkili olduğunu düşündükleri belirlenmiştir (Ayık ve Ada, 2009; Kanmaz ve Uyar, 2016; Yıldırım ve Ada, 2015; Yılmaz, 2015). Öğrencilerin nitelikli şekilde yetiştirilebilmesinde okul etkililiğinin önemli olduğu düşünüldüğünde okulların etkililiğinin üst düzeye çıkarılmasının gerekli olduğu ifade edilebilir.

Sınıf öğretmenleri okul müdürlerinin etkili liderlik niteliklerine orta düzeyde sahip oldukları düşünmektedirler. Günümüzde eğitim kurumlarından beklentilerin artması okul liderlerinin sorumluluğunun artmasına yol açmaktadır (Mulford, 2003). Çağdaş toplumun ihtiyaçları eğitim sistemine adapte etmek istendiği için okul liderlerinin rol ve sorumlulukları 
artmış ve yoğunlaşmıştır. Okulların artan özerkliği ve hesap verebilirliği okul liderliğini öncekinden daha önemli hale getirmiştir (Odhiambo ve Hii, 2012). Bu nedenle okul müdürlerinin liderlik becerilerinin neler olması gerektiği, bu becerilere ne derece sahip oldukları ve bunları uygulamaya dönüştürme düzeylerinin ne olduğu konusunda çeşitli araştırmalar yapılmıştır (Boonla ve Treputtharat, 2014; Day, Harris, Hadfield, Tolley ve Beresford, 2000; Laila, 2015; Sammons v.d. 2011; Sharma, 2010). Bu çalışmaların bazılarında öğretmenler, okul liderlerinin dürüst, iletişim becerisine sahip, katılımı benimseyen, destekleyici, okul için açık bir vizyona sahip olmalarını istemektedirler (Bolanle, 2013; Day v.d., 2000; Laila, 2015). Sharma (2010) tarafından yapılan çalışmada da öğretmenler etkili okul liderlerinin teknik becerilerden daha çok insancıl niteliklere sahip olmaları gerektiğini düşündükleri bulunmuştur. Okul müdürlerinin liderlik niteliklerine sahip olmalarının nitelikli eğitim faaliyetinin gerçekleştirilmesinde ve okulun performansında çok önemli olduğu (Aubrey, Godfrey ve Harris, 2013) düşünüldüğünde, bu çalışmada okul müdürlerinin orta düzeyde liderlik niteliklerine sahip olmalarının istenilen bir durum olmadığı ifade edilebilir.

Bu çalışmada okul müdürlerinin etkili liderlik niteliklerine sahip olma düzeyleri ile okul etkililiği arasında olumlu ilişki olduğu ortaya çıkmıştır. Alan yazında bu konuyla ilgili yapılan çalışmaların çoğunluğunda araştırmada elde edilen bulguyu destekler şekilde okul liderliği ile okul etkililiği arasında olumlu ilişkinin olduğu bulunmuştur (Bolanle, 2013; Boonla ve Treputthrat, 2014; Hallinger ve Heck, 2010; Hofman ve Hofman, 2011; Sammons v.d., 2011; Tatlah ve Iqbal, 2012; Yılmaz, 2010). Okul müdürleri okulun insan ve madde kaynaklarını kullanma sorumluluğuna sahiptirler (Laila, 2015). Dolayısıyla müdürler okulun kaynaklarını etkili şekilde yönlendirerek öğretimin nitelikli şekilde gerçekleştirilmesini sağlamadan birincil derecede yükümlü olan kişilerdir. Okulların etkili olabilmesi yaratıcı düşünme becerisine, alanındaki değişimi öngörebilme, yardım edebilme kapasitesine, nitelikli eğitimi güvence altına alabilme, kaynakları etkili kullanma, bütün çocukların öğrenmelerini artırmak için mesleki liderlik yapabilme yeterliliğine sahip olan liderlere bağlıdır (Laila, 2015). Hızlı şekilde değişen ve çok fazla teknoloji yönelimli bir toplumda öğrenciler, okulda ve hayatta başarıya ulaşmak için onlara yardımcı olacak bilgi ve becerileri kazanmaya intiyaç duyacaklardır. Okul çevresinin bu evrilen doğası eğitim liderlerinden yüksek taleplerin ortaya çıkmasına neden olmaktadır (Fook ve Sidho, 2009). Bu açıdan okulların etkili şekilde eğitim hizmeti verebilmeleri okul müdürlerinin liderlik niteliklerine sahip olmalarını gerektirmektedir. Bu çalışmada da okul müdürlerinin etkili liderlik niteliklerine sahip olmalarının öğretmenlerin okul etkililiğine ilişkin algıları üzerinde olumlu etkisinin olduğu bulunmuştur. Bununla birlikte araştırma sonuçları, kişilerarası beceriler (etki, rahat ettirme, iletişim ve empati gibi) ve yönetsel becerilere (zaman yönetimi ve karar verme) sahip olan müdürlerin okulların etkililiğine olumlu yönde katkı yaptığını göstermiştir (Bolanle, 2013; Kazancıoğlu, 2008; Laila, 2015). Bu sonuçlarla paralel şekilde bu çalışmada müdürlerin öğretmenlerle ilişki kurabilme becerisini içeren iletişim, etki ve rahat ettirme nitelikleri ile yönetsel becerileri içeren karar verme ve zaman yönetimi gibi niteliklere sahip olmalarının okul etkililiği üzerinde anlamlı ve olumlu etkiye sahip olduğu ortaya çıkmıştır. Ancak alan yazının aksine okul müdürlerinin empati becerilerinin okul etkililiği üzerinde anlamlı etkisinin olmadığı bulunmuştur. Oysa empati niteliği, öğretmenlerle yakın ilişki kurma ve onları anlamayı vurgulaması nedeniyle öğretmenlerin okullarının etkili şekilde işlemesi için daha fazla çaba göstermelerine neden olabilir. Dolayısıyla empati niteliğinin okul etkililiği üzerinde olumlu katkı yapacağı beklenilen bir durum iken, bu çalışmada bununla 
uyumlu olmayan şekilde empatinin okul etkililiği üzerinde anlamlı etkiye sahip olmadığı ortaya çıkmıştır. Bu sonuç araştırmaya katılan öğretmenlerin, okul müdürlerinin kendileriyle kişisel yakınlık kurma düzeyleriyle öğretim etkinliklerini nitelikli şekilde gerçekleştirebilmek için sorumluluklarını yerine getirmeye yönelik çabalarını birbirinden ayırma eğiliminde olmalarından kaynaklanabilir.

\section{Sonuç ve Öneriler}

Bu çalışmada sınıf öğretmenlerinin okullarının ortalamaya yakın bir düzeyde etkili olduğunu, okul müdürlerinin etkili liderlik niteliklerine orta düzeyde sahip olduklarını düşündükleri ve okul müdürlerinin etkili liderlik niteliklerine sahip olmalarının öğretmenlerin okul etkililiği algıları üzerinde olumlu etkisinin olduğu ortaya çıkmıştır. Bu sonuca göre öğretmenlerin okullarının etkili olduklarını algılayabilmelerini sağlayabilmede okul müdürlerinin etkili liderlik niteliklerine sahip olmalarının önemli olduğu ileri sürülebilir.

Müdürlerin karar alma niteliği ile okul etkililiği arasında ilişkinin varlığına dayalı olarak öğretmenlerin, çalıştıkları okul müdürlerinin karar alabilme niteliğine sahip olduklarını düşündüklerinde okul etkililiği algılarının artacağı ileri sürülebilir. Öğretmenlerin, okulların işleyişi sürecinde yapılması gereken işlemlerin belirlenmesi veya karşılaşılan sorunların çözümü konusunda müdürlerinin beceri sahibi olduğunu düşünmeleri, okulların amaçlarına ulaştıkları algısının oluşmasına, dolayısıyla da okulun etkili olduğunu düşünmelerine yol açabilir. Bu açıdan müdürlerin karar verme becerilerinin geliştirilmesini öğretmenlerin okulların etkili olduğunu düşünmelerine katkı yapabilir.

Öğretmenlerin okul etkililiği algıları ile etkili okul müdürlerinin etkileme becerisine sahip olmaları arasında olumlu ilişkinin olduğu sonuca dayalı olarak, öğretmenlerin okulun etkili olduğunu düşünebilmesi için müdürlerin öğretmenleri etkileyebilme becerisine sahip olmasının gerekli olduğu ifade edilebilir.

Bu çalışmada okul müdürlerinin bağlıık ve rahat ettirme niteliklerinin öğretmenlerin okul etkililiği algılarını olumlu etkilediği ortaya çıkmıştır. Bu sonuca dayalı olarak öğretmenlerin müdürlerinin kendilerine ihtiyaç duyduklarında yardımcı olduklarını, okul başarısı için beklentilerin ötesinde çok çaba gösterdiğini ve okulun amaç ve değerlerine bağlı olduklarını düşünmeleri okul etkililiği algılarına olumlu katkı yapabileceği ifade edilebilir. Bunun için okul müdürleri öğretmenlerin karşılaştıkları problemlerin çözümünde yardımcı olabilirler. Öğretmenlerin sorunlarını rahatlıkla anlatabilecekleri sıcaklığı ve yakınlığı hissettirebilecek bir ilişki kurabilirler. Okul çalışanlarıyla birlikte sosyal etkinliklerde bulanabilirler.

\section{Kaynaklar}

Aubrey, C., Godfrey, R. ve Harris, A. (2013). How do they manage? An investigation of early childhood leadership. Educational Management Administration \& Leadership, 41(1), 529.

Arslan, H., Satıcı, A. ve Kuru, M. (2006). Devlet ve özel ilköğretim okullarının etkililiğinin araştırılması. Eğitim ve Bilim, 31 (142), 15-25.

Ayık, A. ve Ada, Ş. (2009). İlköğretim okullarında oluşturulan okul kültürü ile okulların etkililiği arasındaki ilişki. Gaziantep Üniv. Sosyal Bilimler Enstitüsü Dergisi, 8(2), 429-446.

Babaoğlan, E., Nalbanti, A. ve Çelik, E. (2017). Okul başarısına okul yöneticisinin etkisi. 12. Uluslararası Eğitim Yönetimi Kongresi 11-13 Mayıs 2017, Başkent Üniv., Ankara.

Balcı, A. (2001). Etkili okul. Ankara: Pegem yayıncılık.

Bolanle, A. O. (2013). Principals' leadership skills and school effectiveness: The case of South Western Nigeria. World Journal of Education, 3(5), 26-33. 
Boonla, D. ve Treputtharat, S. (2014). The relationship between the leadership style and school effectiveness in school under the Office of secondary education area 20. Procedia-Social and Behavioral Sciences, 112, 991-996.

Cerit, Y., Kadıoğlu Ateş, H. ve Kadıoğlu, S. (Baskıda). Etkili okul müdürlerinin liderlik nitelikleri ile öğretmenlerin değişime açık olma düzeyleri arasındaki ilişki. Kalem Uluslararası Eğitim ve Insan Bilimleri Dergisi,

Creemers, B. P.M. ve Reezigt, G. (1997). School effectiveness and improvement: Sustaining links. School Effectiveness and Improvement, 8 (4), 96-429.

Day, C., Gu, Q ve Sammons, P. (2016). The impact of leadership on student outcomes: How successful school leaders use transformational and instructional strategies to make a difference. Educational Administration Quarterly, 52(2), 221-258.

Day, C., Harris, A., Hadfield, M., Tolley, H., ve Beresford, J. (2000). Leading schools in times of change. Buckingham: Open University Press.

Edmonds, R. (1979). Effective schools for the urban poor. Educational Leadership, 37 (1), 1524.

Fook, C.Y. ve Sidhu, G.K. (2009). Leadership characteristics of an excellent principal in Malaysia. International Education Studies, 2(4), 106-116.

Fullan, M. (2001). Leading in a culture of change. Jossey-Bass, San Francisco, CA

Hallinger, P. (2010). Leadership for learning: What we have learned from 30 years of empirical research. Paper presented at the Hong Kong School Principals' Conference 2010: Riding the Tide, The Hong Kong Institute of Education, Hong Kong.

Hallinger, P., ve Heck, R. H. (2010). Collaborative leadership and school improvement: Understanding the impact on school capacity and student learning. School Leadership and Management, 30(20), 95-110.

Hallinger, P., Bickman, L. ve Davis, K. (1996). School context, principal leadership, and student reading achievement. The Elementary School Journal, 96 (5), 527-49.

Hofman, W.H.A. ve Hofman, R.H. (2011). Smart management in effective schools: effective management configurations in general and vocational education in the Netherlands. Educational Administration Quarterly, 47 (4), 620-645.

Jacobson, S. (2011). Leadership effects on student achievement and sustained school success. International Journal of Educational Management, 25(1), 33-44.

Kanmaz, A. ve Uyar, L. (2016). Okul etkililiğinin öğrenci başarısı üzerindeki etkisi. International Journal of Assessment Tools in Education, 3(2), 123-136.

Kazancıoğlu, M. M. (2008). Özel okullarda üst düzey yöneticilerin liderlik tarzları ve okul etkililiği üzerine bir çalışma (İstanbul örneği). Yayımlanmamış yüksek lisans tezi, Yeditepe Üniversitesi Sosyal Bilimler Enstitüsü, İstanbul.

Klopf, G., Schelden, E. ve Brennan, K. (1982). The Essentials of effectiveness: A job description for principals. Principal, March, 35-39-8.

Laila, A. (2015). The effective school: The role of the leaders in school effectiveness. Educational Research and Reciews, 10(6), 695-721.

Leithwood, K., Anderson, S., Mascall, B. ve Straus, T. (2010). School leaders' influences on student learning: the four paths. in T. Bush, L. Bell ve D. Middlewood (Eds), The Principles of Educational Leadership and Management. London: Sage.

Mulford, B. (2003). School leaders: Challenging roles and impact on teacher and school effectiveness. $O E C D$

Odhiambo, G., ve Hii, A. (2012). Key stakeholders' perceptions of effective school leadership. Educational Management Administration \& Leadership, 40(2), 232-247.

Parylo, O. ve Zepeda, S.J. (2014). Describing an effective principal's perceptions of the central office leaders. School Leadership \& Management, 34(5), 518-537. 
Purkey, S.C. ve Smith, M.S. (1983). Effective schools: a review. The Elementary School Journal, 83 (4), 427-452.

Reezigt, G. ve Creemers, B. P.M. (2005). A comprehensive framework for effective school improvement. School Effectiveness and School Improvement, 16(4), 407-424.

Sammons, P., Gu, Q., Day, C. ve Ko, J. (2011). Exploring the impact of school leadership on pupil outcomes: results from a study of academically improved and effective schools in England. International Journal of Educational Management, 25(1), 83-101.

Sharma, S. (2010). Preferred leadership qualities of principals-What do teachers prefer? Journal Management \& Leadership, 2, 42-58.

Şenel, T. ve Buluç, B. (2016). İlkokullarda okul iklimi ile okul etkililiği arasındaki ilişki. TÜBAV Bilim, 9 (4), 1-12.

Tatlah, I.A. ve Iqbal, M.Z. (2012). Leadership styles and school effectiveness: Empirical evidence from secondary level. Procedia-Social and Behavioral Sciences, 69, 790-797.

Trujillo, T. (2013). The reincornation of the effective school research: Rethinking the literature on district effectiveness. Journal of Educational Administration, 51(4), 426-452.

Wallin, J. (2003). Improving school effectiveness. ABAC Journal, 23(1), 61-72.

Wang, A.W., Walters, A.M. ve Thum, Y.M. (2013). Identifying highly effective urban schools: Comparing two measures of school success. International Journal of Educational Management, 27(5), 517-540.

Witziers, B., Bosker, R. ve Krüger, M. (2003). Educational leadership and student achievement: The elusive search for an association. Educational Administration Quarterly, 39, 398-425.

Yıldırım, í. (2015). Okul yöneticilerinin kişilik ve denetim odağı özelliklerinin öğretmenlerin iş doyumu ve okul etkililiği açısından incelenmesi. Yayınlanmamış doktora tezi, Atatürk Üniversitesi Eğitim Bilimleri Enstitüsü, Erzurum.

Yıldırım, i. ve Ada, Ş. (2015). Okul müdürlerinin kişilik özellikleri ve denetim odakları ile okul etkililiği arasındaki ilişki. Uluslararası Eğitim Bilimleri Dergisi, 8(2), 429-446.

Yılmaz, E. (2010). ilköğretim okulu müdürlerinin öğretimsel liderlik rolleri ile etkili okul arasındaki ilişkinin değerlendirilmesi. Yayımlanmamış Yüksek Lisans Tezi, Gazi Üniversitesi Eğitim Bilimleri Enstitüsü, Ankara 


\section{SUMMARY}

In many countries educational researchers and politicians have been interested in educating students well. This has resulted in intensively research on the effectiveness of schools (Day, Gu and Sammons, 2016). While some of the studies on school effectiveness focus on the effectiveness levels of schools or on determining the characteristics of effective schools (Hofman and Hofman, 2011; Wang et al., 2013), some studies have focused on factors affecting school effectiveness (Bolanle, 2013; Tatlah and Iqbal, 2012). The results of the various studies have shown that school principals' leadership behaviors are an important factor affecting school effectiveness (Tatlah and Iqbal, 2012). Many studies have indicated the existence of the relationship between principal's effective leadership qualities and school effectiveness (Bolanle, 2013; Kazancıoğlu, 2008; Yılmaz, 2010). The studies examining the relationship between school leadership and school effectiveness, it was found that school leadership had directly or indirectly effect on school effectiveness (Bolanle, 2013; Boonla and Treputthrat, 2014; Sammons et al., 2011; Tatlah and Iqbal, 2012; Yılmaz, 2010). The findings of the study conducted by Yilmaz (2010) indicated that the levels of school principals' fulfillment of instructional leadership behaviors positively affect perceives of teachers' schools effectiveness. Hallinger (2010) stated that principals' leader behaviours have effect on school effectivenes through the building of a collaborative learning culture, a structure and culture that promotes teacher development, and a school climate that promotes the motivation, participation, and success of students. School leaders contribute to the effectiveness of the school by working intensively to create safe and regular learning environments, building instructional objectives, having high expectations for performance from students and teachers, and developing positive family-school collaboration (Jacobson, 2011). Based on these explanations, It can be said that school principal leadership behaviours related to school effectiveness. Although there are some studies in the literature the relationship between principal's effective leadership qualities and school effectiveness, no studies examining the relationship between effective leadership qualities and school effectiveness have been carried out in Turkey. For this reason, this study focuses on the relationship between principal's effective leadership qualities and school effectiveness.

The sample of this study included 257 classroom teachers from 22 primary schools in Bolu. Classroom teachers' perceptions of school effectiveness was measured using perceived school effectiveness scale developed by Hoy (2014) and was adapted by Yıldırım (2015), and effective leadership qualities was measured using effective leadership qualities developed by Sharma (2010) and was adapted by Cerit, Kadıoğlu Ateş and Kadıoğlu (in review).

To determine the consistency of 8 items of school effectiveness scale, and 16 items of the effective leadership qualities scale, confirmatory factor analysis (CFA) performed on data for the sample of this study. The results of CFA for school effectiveness scale indicated that fit index of the 8 items school effectiveness scale showed a good fit to the data $\left(\mathrm{X}^{2}=194.421, \mathrm{df}=58, \mathrm{X}^{2} / \mathrm{df}=3.35, \mathrm{RMSEA}=.05, \mathrm{CFI}=.94, \mathrm{GFI}=.90\right)$. In addition, load values of the items of the scale ranged from .73 to .91 . Consequently, it is revealed that 8 items structure of the scale is a valid structure. Internal reliability was measured by using Cronbach alpha coefficient, and alpha was 0.89 for the scale.

The results of CFA for the effective leadership qualities scale indicated that fit index of the 8 items school effectiveness scale showed a good fit to the data $\left(X^{2}=201.425, d f=54, X^{2} / d f=3.73, R M S E A=.06\right.$, $\mathrm{CFI}=.92, \mathrm{GFI}=.90)$. In addition, load values of the items of the scale ranged from .69 to .94. Consequently, it is revealed that 16 items and 8 factors structure of the scale is a valid structure. Internal reliability was measured by using Cronbach alpha coefficient, and alpha was 0.94 for the scale.

The findings of present study show that the perceptions of classroom teachers' school effectiveness was near the midpoint on the scale. It was found that the perceptions of classroom teachers' their principal with moderate leadership qualities. The rated most effective leadership qualities factor was the principals' time management and self-management by teachers, whereas the rated least effective leadership qualities factor was communication skills by teachers.

The Correlation analysis revealed that there was a significant positively correlation between effective leadership qualities and the perceptions of classroom teachers' school effectiveness. The perceptions of classroom teachers' school effectiveness is the most related to decision making, the lowest related to communication skills. The results of regression analysis indicated that effective leadership qualities had a positive impact on the perceptions of classroom teachers' school effectiveness. 